\title{
Biotin supply by large bowel bacteria in minipigs: evidence from intracaecal avidin
}

\author{
By JOHANNE SCHOLTISSEK, CHRISTIANA. BARTH AND \\ HANS HAGEMEISTER \\ Bundesanstalt für Milchforschung, D-2300 Kiel 1, Federal Republic of Germany \\ AND MARTIN FRIGG \\ Department of Animal Nutrition and Health, F. Hoffmann-La-Roche, CH 4002 Basle, Switzerland
}

(Received 25 September 1989-Accepted 28 June 1990)

\begin{abstract}
The influence of a change of colonic availability of biotin on biotin status was studied. This was done by inhibition of biotin absorption by intracaecal avidin infusion. Five adult minipigs with a permanent caecal ' $T$ ' cannula were fed on a semi-synthetic, biotin-deficient diet for 4 months. Following an 8-week adaptation period there were nine sequential 1-week infusion periods with or without oral lactulose or antibiotics. Avidin infusion during weeks 2,5 and 8 amounted to $18 \mathrm{mg} / \mathrm{d}(13 \mathrm{U} / \mathrm{mg})$. Plasma biotin concentrations were not changed by avidin infusions. There was a significant average $84 \%$ rise in faecal biotin excretion during the avidin periods. Urinary biotin output following avidin decreased by $21 \%$. This is taken as evidence that biotin synthesized by colonic bacteria is available for host metabolism. A rough estimate shows that under basal conditions $1.7-17 \%$ of the metabolic allowance may be covered by this metabolic route.
\end{abstract}

Biotin synthesis: Biotin absorption: Colonic microflora: Minipig

In animals, symptoms of vitamin deficiency (growth retardation, claw lesions) can be induced by feeding a biotin-deficient diet (Bonjour, 1984). In humans, nutritional biotin deficiency seems to occur only in the case of a high intake of avidin interfering with intestinal biotin absorption (Sydensticker et al. 1942; Bonjour, 1984). There is a general belief that in humans dietary biotin may be less important than its provision by intestinal bacteria (Davidson et al. 1979). Investigations of Kopinski \& Leibholz (1985, 1988), Sauer et al. (1988) and Mosenthin et al. (1990) show that there is considerable synthesis of biotin in the large intestine of the pig independent of biotin intake.

However, despite detailed knowledge about the metabolic effects and physiology of this vitamin, the proportion of biotin of dietary origin and that contributed by the intestinal microflora is unknown. This is illustrated by the fact that several national and international agencies do not consider it appropriate to issue recommendations about the dietary intake for this vitamin (Davidson et al. 1979; Food and Nutrition Board, 1980; Deutsche Gesellschaft für Ernährung, 1985). Moreover, lack of knowledge about the quantity of biotin provided by intestinal bacteria prevents its true metabolic requirement from being defined. There are only rough estimates of the metabolic needs, e.g. the recommendation to provide $300 \mu \mathrm{g}(1230 \mathrm{nmol}) / \mathrm{d}$ for adults in the case of total parenteral nutrition (Davidson et al. 1979).

There may be two sites of biotin absorption, the small bowel (Spencer \& Brody, 1964) and the colon (Barth et al. 1986). Microbial synthesis of biotin takes place in the lower part of the intestinal tract where absorption of nutrients is believed to be rather limited (Tagwerker, 1977; Kopinski et al. 1983). Nevertheless one clinical study (Sorrell et al. 1971) 
detected an increase in urinary output of biotin, when biotin was administered into the midtransverse colon of patients with colostomies. An absorptive capability of the large bowel for biotin was demonstrated in pigs (Barth et al. 1986) and in rats (Bowman \& Rosenberg, 1987). In an attempt to define the contribution of the intestinal microflora we have followed variables of biotin nutriture during inhibition of its colonic absorption by intracaecal avidin infusion.

\section{MATERIALS AND METHODS}

\section{Materials}

Avidin from egg white, lyophilized, (13 U/mg; $1 \mathrm{U}$ binds $1 \mu \mathrm{g}$ biotin), was purchased from Serva, Heidelberg, West Germany.

\section{Animals}

Five male Göttingen minipigs (age 2-3 years), each fitted with a permanent caecal ' $T$ ' cannula, were individually housed in metabolism cages with slatted floors to prevent coprophagy. Room temperature was $20 \pm 2^{\circ}$ and humidity ranged from 60 to $70 \%$; light was on from 06.00 to 19.00 hours. The diet was given in two equal portions at 06.00 and 15.00 hours. Water was available ad lib.

\section{Diet}

A semi-synthetic, low-fibre diet with an energy content of $17.6 \mathrm{MJ}$ metabolizable energy (ME) $/ \mathrm{kg}$ dry matter was composed as shown in Table 1 to meet maintenance requirements (0.44 MJ ME $/ \mathrm{kg}$ body-weight $\mathrm{t}^{0.75}$ per $\mathrm{d}$ ). The pigs were given daily a semi-synthetic diet of $433 \mathrm{~g}$ (approximately $400 \mathrm{~g}$ dry matter) supplemented with $157 \mathrm{nmol}(38 \mu \mathrm{g})$ biotin, which amounted to about $25 \%$ of the dietary allowance of $150 \mu \mathrm{g} / \mathrm{d}$ per animal for growing pigs proposed by Tagwerker (1983) if the body-weight of minipigs is taken into account. The initial body-weight was 35.8 (SE 1.7) $\mathrm{kg}$ and increased to 38.0 (SE 1.2) $\mathrm{kg}$ during the trial. Supplements to the diet are described on p. 717.

\section{Experimental procedure}

The experiment consisted of a 2-month adjustment period followed by nine-sequential 1-week infusion periods (see Table 2 ) with or without oral lactulose $(26 \mathrm{~g} / \mathrm{d}$ ) or antibiotics (250 mg Veomycin sulphate/d and $300 \mathrm{mg}$ Bacitracin/d). Lactulose was given to alter the intestinal flora and increase bacterial biotin synthesis. Antibiotic treatment was carried out to reduce biotin-synthesizing or biotin-utilizing micro-organisms in the intestine, or both. Avidin (18 $\mathrm{mg} / \mathrm{d}$ ) dissolved in $200 \mathrm{ml}$ water was continuously infused during weeks 2,5 and 8 . This amount of avidin can bind $960 \mathrm{nmol}$ biotin. Water $(200 \mathrm{ml} / \mathrm{d})$ was infused during weeks $1,3,4,6,7$ and 9 (solvent control).

Total urine was collected for $24 \mathrm{~h}$ on crushed ice during the last $2 \mathrm{~d}$ of each week and subsequently stored at $-20^{\circ}$. Faeces of the last $3 \mathrm{~d}$ were collected, pooled, lyophilysed and stored at room temperature. Before the morning feed on the last day of each week blood samples were collected by puncture of the vena jugularis. Plasma was obtained by anticoagulation with heparin $(143 \mathrm{USP} / 10 \mathrm{ml})$ and stored at $-20^{\circ}$ before determination of biotin.

\section{Analytical procedures}

Biotin concentrations in plasma, faeces and urine were determined using the microbiological procedure of Frigg \& Brubacher (1976). The test organism was Lactobacillus plantarum (ATCC 8014). 
Table 1. Composition of diet $(\mathrm{g} / \mathrm{kg})$

\begin{tabular}{lr}
\hline Ingredients & \\
\hline Maize starch & $310 \cdot 0$ \\
Saccharose & $250 \cdot 0$ \\
Casein & $150 \cdot 0$ \\
Margarine & $75 \cdot 0$ \\
Lard & $75 \cdot 0$ \\
Cellulose & $59 \cdot 4$ \\
Mineral + vitamin premix* & $80 \cdot 0$ \\
Cholesterol & $0 \cdot 6$ \\
\hline
\end{tabular}

* Minerals and vitamins in the diet $(\mathrm{g} / \mathrm{kg})$ : calcium $10 \cdot 85$, phosphorus $6 \cdot 13$, chloride 4.61 , magnesium 4.03 , potassium $5 \cdot 10$, sodium $3 \cdot 88,(\mathrm{mg} / \mathrm{kg})$ : copper $40 \cdot 0$, iron $200 \cdot 0$, manganese $100 \cdot 0$, zinc $200 \cdot 0$, bromine $13 \cdot 6$, fluoride $3 \cdot 8$, iodine $1 \cdot 2$, selenium 0.5 , nickel $1 \cdot 88$, cobalt $0 \cdot 8$, molybdenum $1 \cdot 98$, arsenate $0 \cdot 15$, boron 0.55 , retinyl acetate $18 \cdot 15$, cholecalciferol $0 \cdot 16$, choline chloride $2580 \cdot 0$, ascorbic acid $585 \cdot 0, \alpha$-tocopheryl acetate $300 \cdot 0$, nicotinic acid $75 \cdot 5$, Ca pantothenate $67 \cdot 5$, menadione $24 \cdot 0$, riboflavin $22 \cdot 4$, pyridoxal hydrochloride $19 \cdot 7$, thiamin hydrochloride $8 \cdot 9$, pteroylmonoglutamic acid $5 \cdot 4$, biotin $0 \cdot 088$, cyanocobalamin $0 \cdot 16$.

Table 2. Plasma biotin concentrations following different oral supplements and intracaecal avidin

\begin{tabular}{|c|c|c|c|c|}
\hline \multirow{2}{*}{$\begin{array}{l}\text { Week of } \\
\text { experiment }\end{array}$} & \multirow{2}{*}{$\begin{array}{l}\text { Oral } \\
\text { supplement }\end{array}$} & \multirow{2}{*}{$\begin{array}{l}\text { Intracaecal } \\
\text { infusion }\end{array}$} & \multicolumn{2}{|c|}{$\begin{array}{l}\text { Plasma biotin* } \\
\quad(\mathrm{nmol} / \mathrm{l})\end{array}$} \\
\hline & & & Mean & $S E$ \\
\hline 1 & - & Solvent & 1.7 & 0.1 \\
\hline 2 & - & Avidin & 1.9 & 0.2 \\
\hline 3 & - & Solvent & 1.8 & 0.4 \\
\hline 4 & Lactulose & Solvent & 1.9 & 0.4 \\
\hline 5 & Lactulose & Avidin & 1.8 & $0 \cdot 2$ \\
\hline 6 & Lactulose & Solvent & $2 \cdot 0$ & 0.2 \\
\hline 7 & Antibiotics & Solvent & $2 \cdot 0$ & 0.2 \\
\hline 8 & Antibiotics & Avidin & 1.6 & $0 \cdot 2$ \\
\hline 9 & Antibiotics & Solvent & 1.8 & $0 \cdot 3$ \\
\hline
\end{tabular}

* There were no statistically significant differences.

\section{Statistics}

Due to the unequal number of observations per animal, least square procedures were applied to estimate means, standard errors and contrasts (Searle, 1971). A model was adopted including fixed effects of animal, infusion (solvent before avidin, avidin, solvent after avidin), supplement (basal diet, lactulose, antibiotics) and interaction of infusion $\times$ supplement. The computer program LSML 76 (Harvey, 1976) was applied.

\section{RESULTS}

During the whole 17 -week period there were no clinical symptoms of biotin deficiency. Plasma biotin concentrations tended to be lower during intracaecal avidin infusion between weeks 4 and 9 ; however, these somewhat lower values were not significantly different from those for their controls (Table 2).

There was a significant average $84 \%$ increase in faecal biotin during avidin infusions demonstrating the efficient binding of the vitamin (Fig. 1). An average faecal biotin 


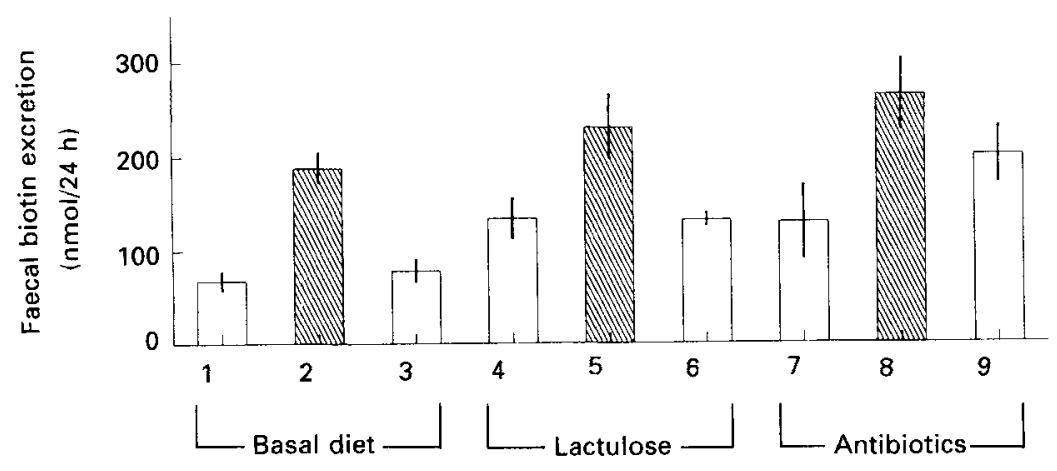

Period of experiment (weeks)

Fig. 1. Faecal biotin loss during avidin infusions ( or solvent controls ( $\square$ ). Values are means with their standard errors represented by vertical bars for five minipigs. The means of all avidin infusion periods proved to be significantly different $(P<0.05)$ from those for all solvent control periods. For details of procedures, see pp. $716-717$.

Table 3. Urinary biotin excretion following different oral supplements and intracaecal avidin

\begin{tabular}{|c|c|c|c|c|}
\hline \multirow{2}{*}{$\begin{array}{c}\text { Week of } \\
\text { experiment }\end{array}$} & \multirow{2}{*}{$\begin{array}{l}\text { Oral } \\
\text { supplement }\end{array}$} & \multirow{2}{*}{$\begin{array}{l}\text { Intracaecal } \\
\text { infusion }\end{array}$} & \multicolumn{2}{|c|}{$\begin{array}{l}\text { Urinary biotin } \\
\text { excretion } \\
\text { (nmol/24h) }\end{array}$} \\
\hline & & & Mean & $\mathrm{SE}$ \\
\hline 1 & - & Solvent & $93 \cdot 5$ & $17 \cdot 6$ \\
\hline 2 & - & Avidin & $85 \cdot 3$ & $11 \cdot 3$ \\
\hline 3 & - & Solvent & $97 \cdot 2$ & $9 \cdot 1$ \\
\hline 4 & Lactulose & Solvent & $106 \cdot 4$ & $12 \cdot 8$ \\
\hline 5 & Lactulose & Avidin & $93 \cdot 2$ & 3.9 \\
\hline 6 & Lactulose & Solvent & $102 \cdot 4$ & $9 \cdot 0$ \\
\hline 7 & Antibiotics & Solvent & $125 \cdot 3$ & 13.9 \\
\hline 8 & Antibiotics & Avidin & 77.9 & $18 \cdot 8$ \\
\hline 9 & Antibiotics & Solvent & $125 \cdot 5$ & $9 \cdot 0$ \\
\hline
\end{tabular}

excretion during avidin infusion of $230 \mathrm{nmol} / \mathrm{d}$ corresponded to $24 \%$ of the biotin-binding capacity of the avidin infused.

Table 3 summarizes changes in urinary biotin excretion. Avidin infusions caused lower urinary biotin concentrations. When multifactorial statistics were applied, the urinary biotin excretion of all 'avidin' weeks compared with all 'non-avidin' weeks proved to be significantly lower $(P<0.01)$. The interaction infusion $\times$ supplement was not significant $(P=0 \cdot 2)$. Differences between animals were significant $(P<0 \cdot 01)$, whereas effects of oral supplements were not $(P=0.09)$.

\section{DISCUSSION}

It was our aim to study the influence of a change in colonic availability of biotin on biotin nutriture. The method chosen proved to be efficient as an $84 \%$ increase in faecal biotin excretion was observed. Surprisingly no significant change in plasma biotin was observed. In piglets a good correlation between plasma biotin and biotin nutriture has been observed 
by several investigators (Christensen, 1980; Bryant et al. 1985; Misir \& Blair, 1986; Streiff et al. 1986). However, urinary biotin excretion was lowered by $21 \%$ in our experiments showing some supply by colonic bacteria.

To substantiate further such a contribution two oral supplements were given, known to alter colonic microflora. Lactulose and antibiotics both led to higher rates of faecal and urinary biotin excretion, showing that biotin-producing or biotin-requiring bacteria were indeed changed, leading to a higher net biotin production.

Earlier experiments with sulphonamides and antibiotics gave inconclusive results. Some investigators have reported a reduction in faecal biotin output (Oppel, 1942; Grundy et al. 1947) and urinary excretion by streptomycin (Sarett, 1952). Markkanen (1960) observed no effect of neomycin on urinary biotin excretion. The rise in faecal biotin excretion associated with antibiotic treatment is in accordance with earlier findings of a higher liver biotin concentration in poultry following antibiotic supplementation (Buenrostro \& Kratzer, 1983). The evidence presented may also be taken to estimate the supply of biotin by colonic bacteria. For this purpose we have made the following assumptions: (1) avidin does not interfere with bacterial biotin synthesis and degradation, (2) trapping of endogenous (e.g. biliary) or non-absorbed dietary biotin by avidin is negligible because the quantities from these sources can be assumed to be relatively low due to the low dietary intake, (3) avidin is not absorbed because of its high molecular weight of $53.1 \mathrm{kDa}$; in fact no colonic avidin absorption has been described in the literature to the best of our knowledge, (4) there is no degradation of avidin in the alimentary tract (György \& Langer, 1968). Therefore, release of biotin from the avidin-biotin complex can be excluded.

If one accepts these premises one can roughly estimate the quantity of biotin provided by the colonic microflora. If one considers the decrease in urinary biotin by avidin during weeks 1-6 (basal and lactulose) a value of $10.6 \mathrm{nmol} / 24 \mathrm{~h}$ is obtained.

If one bases the calculation on the increase in faecal biotin excretion by avidin in our experiments (Fig. 1) the value will be $102 \mathrm{nmol} / 24 \mathrm{~h}$.

The question about the metabolic biotin requirement of swine remains unanswered by the present investigation. This can be estimated properly only by experiments with gnotobiotic animals. However, if one accepts the recommended dietary requirement proposed by Kopinski \& Leibholz (1989) of $410 \mathrm{nmol} / \mathrm{kg}$ feed and that these animals consumed $1.5 \mathrm{~kg}$ feed $/ \mathrm{d}$, our findings would imply that about $1.7 \%$ of the requirement is satisfied by intestinal bacteria under basal conditions and that about $17 \%$ may be satisfied if based on the increase of faecal biotin by avidin. The former value is lower than earlier estimates of Kopinski \& Leibholz $(1985,1988)$ and W. Drochner and L. Völker (unpublished results) who reported that about $10 \%$ of the biotin requirement is provided by intestinal microflora.

The efficient technical assistance of Mrs K. Gonda, and the care of the experimental animals by $\mathrm{Mr} \mathbf{H}$. Fischer and $\mathrm{Mr} \mathrm{J}$. Kunze are gratefully acknowledged. The authors thank Mrs J. Engler and Dr U. Manz, Hoffmann-La-Roche, Basle, for carrying out the biotin assays.

\section{REFERENCES}

Barth, C. A., Frigg, M. \& Hagemeister, H. (1986). Biotin absorption from the hindgut of the pig. Journal of Animal Physiology and Animal Nutrition 55, 128-134.

Bonjour, J.-P. (1984). Biotin. In Handbook of Vitamins, pp. 403-435 [L. J. Machlin, editor]. New York and Basel: Marcel Dekker.

Bowman, B. B. \& Rosenberg, I. H. (1987). Biotin absorption by distal rat intestine. Journal of Nutrition 117, 2121-2126. 
Bryant, K. L., Kornegay, E. T., Knight, J. W., Webb, K. E. \& Notter, D. R. (1985). Supplemental biotin for swine. I. Influence on feedlot performance, plasma biotin and toe lesions in developing gilts. Journal of Animal Science 60, 136-144.

Buenrostro, J. L. \& Kratzer, F. H. (1983). Effect of lactobacillus inoculation and antibiotic feeding of chickens on availability of dietary biotin. Poultry Science 62, 2022-2029.

Christensen, K. (1980). Evaluation of the background for determination of vitamin requirements in pigs. Livestock Production Science 7, 569-590.

Davidson, S., Passmore, R., Brock, J. F. \& Truswell, A. S. (1979). Water-soluble vitamins. In Human Nutrition and Dietetics, 7th ed, pp. 150-151 [S. Davidson and R. Passmore, editors]. Edinburgh, London, New York: Churchill Livingstone.

Deutsche Gesellschaft für Ernährung (1985). Empfehlungen für die Nährstoffzufuhr, 4th revised ed., p. 82. Frankfurt am Main: Umschau Verlag.

Food and Nutrition Board (1980), Recommended Dietary Allowances. Washington, DC: National Academy of Sciences.

Frigg, M. \& Brubacher, G. (1976). Biotin deficiency in chicks fed a wheat-based diet. International Journal of Vitamin Nutrition Research 46, 314-321.

Grundy, W. E., Freed, M., Johnson, H. C., Henderson, C. R., Berryman, G. H. \& Friedmann, T. E. (1947). The effect of phthalylsulfathiazole (sulfathalidine) on the excretion of B-vitamins by normal adults. Archives of Biochemistry and Biophysics 15, 187-194.

György, P. \& Langer, B. W. Jr (1968). Biotin. In The Vitamins, vol. 2, 2nd ed., pp. 316-322 [W. H. Sebrell Jr and R. S. Harris, editors]. London, New York: Academic Press.

Harvey, W. R. (1976). Mixed Model and Maximum Likelihood General Purpose Computer Program. Ohio: Ohio State University.

Kopinski, J. S., Bryden, W. L. \& Leibholz, J. (1983). Biotin synthesis and absorption in the pig. Proceedings of the Nutrition Society of Australia 8, 205.

Kopinski, J. S. \& Leibholz, J. (1985). Post-ileal absorption of biotin in the pig. Proceedings of the Nutrition Society of Australia 10, 170.

Kopinski, J. S. \& Leibholz, J. (1988). Post-ileal absorption of biotin. Proceedings of 4th International Seminar on Digestive Physiology in the Pig, Jablona, Poland.

Kopinski, J. S. \& Leibholz, J. (1989). Biotin studies in pigs. 2. The biotin requirement of the growing pig. British Journal of Nutrition 62, 761-766.

Markkanen, T. (1960). Studies on the urinary excretion of thiamine, riboflavin, nicotinic acid, pantothenic acid and biotin in achlorhydria and after partial gastrectomy. Acta Medica Scandinavica 169, Suppl. 1, 1-55.

Misir, R. \& Blair, R. (1986). Effect of biotin supplementation of barley-wheat diet on restoration of healthy feet, legs and skin of biotin-deficient sows. Research in Veterinary Science 40, 212-218.

Mosenthin, R., Sauer, W. C., Völker, L. \& Frigg, M. (1990). Synthesis and absorption of biotin in the large intestine of pigs. Livestock Production Science 25, 95-103.

Oppel, T. W. (1942). Studies of biotin metabolism in man. American Journal of the Medical Sciences 204, 856875.

Sarett, H. P. (1952). Effect of oral administration of streptomycin on urinary excretion of $\mathbf{B}$ vitamins in man. Journal of Nutrition 47, 275-287.

Sauer, W. C., Mosenthin, R. \& Ozimek, L. (1988). The digestibility of biotin in protein supplements and cereal grains for growing pigs. Journal of Animal Science 66, 2583-2589.

Searle, S. R. (1971). Linear Models. New York: John Wiley.

Sorrell, M. F., Frank, O., Thomson, A. D., Aquino, H. \& Baker, H. (1971). Absorption of vitamins from the large intestine in vivo. Nutrition Reports International 3, 143-148.

Spencer, R. P. \& Brody, K. R. (1964). Biotin transport by small intestine of rat, hamster and other species. American Journal of Physiology 206, 653-657.

Streiff, K., Völker, L. \& Frigg, M. (1986). Availability of biotin from feed ingredients to the growing pig. Proceedings of the 6th International Conference on Production Disease in Farm Animals, pp. 112-115 [C. H. McMurray, editor]. Belfast.

Sydenstricker, V. P., Singel, S. A., Briggs, A. P., De Vaughn, N. M. \& Isbell, H. (1942). Observations of the 'egg white injury' in man and its cure with a biotin concentrate. Journal of the American Medical Association 118 , 1199-1200.

Tagwerker, F. J. (1977). Biotin in pigs. Nippon Roche Feed Seminars, Tokyo and Osaka: Roche Information Service Bulletin no. 1675. Basle: Hoffmann-La-Roche.

Tagwerker, F. J. (1983). Biotin in poultry and swine nutrition. Feed International 1-9. 